\title{
Cognitive Function in Children with Epilepsy
}

\author{
Putra BP1, Triono $A^{2}$, Susilawati $D^{3}$
}

\section{Abstract}

Introduction: Epilepsy is a worldwide and common child health problem. One of its complications is cognitive impairment that will impact on children's cognitive development and quality of life. The objective of this study is to find out whether epilepsy affects cognitive function in children. Material and Methods: This was a cross-sectional descriptive study using secondary data from medical records. We collected data from children with epilepsy from 2004 until 2014 that have been actively managed in the Growth and Development Clinic, Sardjito General Hospital, Yogyakarta, Indonesia. Cognitive function referred to low IQ score that was gained from patients' data. We analyzed the data using Fischer's exact and two-sample Kolmogorov-Smirnov test methods. Results: Among 40 data samples, there were 19 patients $(42.5 \%)$ with cognitive impairment $(I Q<70)$ and 21 patients $(57.5 \%)$ without cognitive impairment $(I Q \geq 70)$. There were twenty-five patients examined by the Stanford-Binet IQ test, which found 15 patients with cognitive impairment. In fifteen patients who were examined with the WISC test, we found more children with epilepsy without cognitive impairment (11 patients). Comorbidity with neuro-developmental disorder significantly affected cognitive impairment in children with epilepsy ( $p$ value $=0.034,95 \%$ $\mathrm{Cl}$ 1.08-21.76). Conclusions: More children with epilepsy without cognitive impairment were found. Further studies are needed with larger number of samples utilizing a prospective study design to better determine the association of epilepsy in children and cognitive impairment.

Key words: epilepsy, children, cognitive impairment, seizures, comorbidity

\section{Introduction}

$E^{p}$ pilepsy is a worldwide and common child health problem, defined as recurrent seizure for minimum of two unprovoked episodes, presentofepilepticsyndromeprovenbyEEG(electroencephalography), and present of one unprovoked episode which its recurrent risk in 10 years similar with two unprovoked episodes according to the ILAE (International League Against Epilepsy). This disease is caused by an imbalance in the brain's neurochemicals, structural brain lesions,
${ }^{1}$ Dr. Bayu Pratama Putra Medical Doctor, Universitas Gadjah Mada, Indonesia, 2 Dr. Agung Triono, Division of Neurology, Department of Child Health, Medical School, Universitas Gadjah Mada/ Sardjito Hospital, Yogyakarta, Indonesia, ${ }^{3}$ Dwi Susilawati, Division of Growth of Development, Department of Child Health, Medical School, Universitas Gadjah Mada/ Sardjito Hospital, Yogyakarta, Indonesia.

\section{Address for correspondence}

Dr. Agung Triono, Consultant in Neurology, Division of Neurology, Department of Child Health, Medical School, Universitas Gadjah Mada/ Sardjito Hospital,

Yogyakarta, Indonesia

Phone/Fax No: +62 274541565

Tel No; +6281328253998

E-mail: agungtrionodr@yahoo.com

\section{Acknowledgements: None \\ Funding: Nil \\ Conflict of Interest: None \\ Permission from IRB: Yes}

\section{How to cite}

Putra BP, Triono A, Susilawati D. Cognitive Function in Children with Epilepsy. J Nepal Paediatr Soc 2018;38(2):74-79.

doi: http://dx.doi.org/10.3126/jnps.v38i2.19386

This work is licensed under a Creative Commons Attribution 3.0 License. 
or genetic disorder that will increase brain neuronal cell excitation, resulting in focal or general brain seizure depending on the location of hyper-excited cells ${ }^{1}$. There are 50 million children with epilepsy worldwide according to World Health Organization². However, there is no clear prevalence data concerning Indonesian children with epilepsy, although it is thought to have prevalence of about $0.4 \%^{3}$. Epilepsy will impact on an individual's neurological, psychological, cognitive, and social aspects, resulting in decreased quality of life. This negative impact will be a burden for the patients and the parents or care providers.

One of the complications of epilepsy is cognitive impairment $(\mathrm{Cl})$. It is defined as an individual's incapability in learning, remembering, applying, analyzing, executive function and working memory. Cognitive assessment in children commonly uses an Intelligence Quotient (IQ) test, such as the Stanford-Binet and the Wechsler Intelligence Scale for Children (WISC) to obtain an IQ score. Both tests have a similar range for its validity and reliability, at 0.80-0.99 points ${ }^{4,5}$. In children with epilepsy, continuing seizures will increase risk of $\mathrm{Cl}$ and often they have less completed formal education compared to healthy children. This education challenge also affects their IQ score result, which can be seen in several previous studies that showed that children with epilepsy had lower IQ scores than non-epileptic children ${ }^{6,7}$.

A number of factors contribute to this $\mathrm{Cl}$, including first-time seizure onset, type of epilepsy and seizure, time and type of antiepileptic drug (AED) given, presence of neuro-developmental disorder as a comorbidity, CT scan/MRI and EEG recording, and also the history of status epilepticus (SE) and family seizure. Identifying how far epilepsy and its factors affect cognitive function in children will help minimize by early intervention in order to improves quality of life and reduce its negative impact on cognitive development.

\section{Material and Methods}

This research was an observational cross-sectional study using secondary data from patients' medical records. All medical records of children with epilepsy from 2004 were gathered until 2014 that have been actively managed in the Child and Development Clinic, Department of Child Health, Sardjito General Hospital, Yogyakarta, Indonesia and had scores from an IQ test using Stanford-Binet or WISC. CI was defined as a child having an IQ score lower than 70 points $^{8}$, scored by either IQ test. A questionnaire is used as a guide to collect data from the medical records. From a total of 78 patients eligible for analysis only 40 data samples were included because of incomplete or unavailable data in the medical records.

Data were inputted into Statistical Packages for Social Sciences/SPSS version 19. Variables including age of patient, educational status, first-time seizure onset, type of epilepsy and seizure, family history of epilepsy and status epilepticus, comorbid neurodevelopmental disorder, time and type of AED usage, and also EEG recording and CT scan / MRI brain. IQ scores were used to compare the number of patients with $\mathrm{Cl}$ in boys and girls with epilepsy. Age of patients was defined as numerical data and the other variables as categorical. All the data, except sex and education status of patient, were analyzed for significance effect to IQ score.

Variables were counted to determine their frequency for the basic characteristics of patients. Before starting the analyses, we conducted a Shapiro-Wilk normality test. Data were analyzed with Fischer's exact test for all bivariate analyses and used two-sample KolmogorovSmirnov test only for type of AED given. Significant results were determined with $p$ value $<0.05$ and $95 \%$ Confidence Interval $(\mathrm{Cl})$.

This study received ethical approval from the Medical Research Ethics Committee of Faculty of Medicine, Universitas Gadjah Mada, Yogyakarta, Indonesia.

\section{Results}

Among 40 patients, there were $77.5 \%$ generalized seizure children and among them $57.5 \%$ were idiopathic etiologies. Absence of family history of epilepsy were found in $90 \%$ and $85 \%$ of the children did not present in status epilepticus. Sixty-five percent of the patients were likely to have a comorbid neuro-developmental disorder such as mental retardation, ADHD, and cerebral palsy. Results showed $50 \%$ of the patients with one type of AED drug given, and many had more than 2 seizure episodes (82.5\%). Abnormal imaging of CT scan and EEG were seen in children with epilepsy, respectively $25 \%$ and $85 \%$. Patient characteristics data are displayed in Table 1.

Twenty one children with epilepsy (52.5\%) were without $\mathrm{Cl}$ (IQ score $\geq 70$ ), compared to 19 patients $(47.5 \%)$ with $\mathrm{Cl}$. In our setting, 25 patients $(62.5 \%)$ were examined using the Stanford-Binet IQ test, which found more children with $\mathrm{Cl}$ (15 patients). Contrary to the WISC test, in 15 patients $(37.5 \%)$ we found more children with epilepsy without $\mathrm{Cl}$ (11 patients). Data concerning IQ scores are displayed in Table 2 and 3. 
In our study, only presence of neuro-developmental disorder significantly correlated with IQ score in children with epilepsy $(p$ value $=0.034,95 \% \mathrm{Cl} 1.08-21.76$ ) Twenty-seven children with epilepsy had neurodevelopmental disorder, including 16 patients with
$I Q<70$ and 11 patients with $I Q \geq 70$. The remaining variables were not significantly affect IQ score with $p$ value $>0.05$. Statistical results which were determined using Fischer's exact and Kolmogorov-Smirnov tests are shown in Table 4.

Table 1. Basic Characteristics of Patients

\begin{tabular}{|c|c|c|}
\hline \multicolumn{2}{|c|}{ Variables } & $\mathbf{N}(\%)$ \\
\hline \multirow{2}{*}{ Sex } & Men & $23(57.5)$ \\
\hline & Women & $17(42.5)$ \\
\hline \multirow{4}{*}{ Education Status } & Not Yet Schooled & $14(35)$ \\
\hline & Elementary School & $23(57.5)$ \\
\hline & Junior High School & $2(5)$ \\
\hline & Senior High School & $1(2.5)$ \\
\hline \multirow{2}{*}{ First-time Seizure Onset } & $<1$ year & $8(20)$ \\
\hline & $\geq 1$ year & $32(80)$ \\
\hline \multirow{2}{*}{ Etiology of Epilepsy } & Symptomatic & $17(42.5)$ \\
\hline & Idiopathic & $23(57.5)$ \\
\hline \multirow{2}{*}{ Type of Seizure } & Focal & $9(22.5)$ \\
\hline & General & $31(77.5)$ \\
\hline \multirow{2}{*}{ History of Family Seizure } & Presence & $4(10)$ \\
\hline & Absence & $36(90)$ \\
\hline \multirow{4}{*}{$\begin{array}{l}\text { Neuro-developmental disorder } \\
\text { comorbidity }\end{array}$} & Mental Retardation & $23(88.5)$ \\
\hline & ADHD & $2(7.7)$ \\
\hline & Cerebral Palsy & $1(3.8)$ \\
\hline & Absence & $14(35)$ \\
\hline \multirow{4}{*}{ Type of Anticonvulsant Usage } & 1 type & $20(50)$ \\
\hline & 2 types & $12(32.5)$ \\
\hline & 3 types & $2(5)$ \\
\hline & $>3$ types & $3(7.5)$ \\
\hline \multirow{2}{*}{ Time of Anticonvulsant Usage } & 2 seizure episodes & $4(10)$ \\
\hline & $>2$ seizure episodes & $33(82.5)$ \\
\hline \multirow{2}{*}{ EEG Recording } & Normal & $2(5)$ \\
\hline & Abnormal & $34(85)$ \\
\hline \multirow{2}{*}{ CT Scan Imaging } & Normal & $4(10)$ \\
\hline & Abnormal & $10(25)$ \\
\hline
\end{tabular}

Legends: EEG: Electroencephalography, CT scan: Computer Topography scan

Table 2: IQ Scores in Children with Epilepsy

\begin{tabular}{ccccc}
\hline & IQ Score & N (\%) & Male (\%) & Female (\%) \\
\hline \multirow{3}{*}{$\mathrm{IQ}<70$} & $<25$ & $1(2.5)$ & $1(2.5)$ & $0(0)$ \\
\cline { 2 - 5 } & $25-44$ & $1(2.5)$ & $1(2.5)$ & $0(0)$ \\
\cline { 2 - 5 } & $45-69$ & $17(42.5)$ & $9(22.5)$ & $8(20)$ \\
\hline & Total & $19(47.5)$ & $11(27.5)$ & $3(7.5)$ \\
\hline & $70-79$ & $8(20)$ & $5(12.5)$ & $1(2.5)$ \\
\hline & $80-89$ & $3(7.5)$ & $2(5)$ & $5(12.5)$ \\
\hline & $90-109$ & $7(17.5)$ & $2(5)$ & $0(0)$ \\
\hline
\end{tabular}

Legends: IQ: Intelligence Quotient 
Table 3. IQ Scores Classification in Children with Epilepsy

\begin{tabular}{ccccc}
\hline \multicolumn{2}{r}{ IQ Score Classification } & $\mathbf{N}(\%)$ & Male (\%) & Female (\%) \\
\hline \multirow{3}{*}{ Stanford-Binet } & $\mathrm{IQ}<70$ & $15(60)$ & $9(56.25)$ & $6(40)$ \\
\cline { 2 - 5 } & $\mathrm{IQ} \geq 70$ & $10(40)$ & $7(43.75)$ & $3(60)$ \\
\cline { 2 - 5 } WISC & Total & $25(62.5)$ & $16(64)$ & $9(36)$ \\
& $\mathrm{IQ}<70$ & $4(26.7)$ & $2(13.3)$ & $2(13.3)$ \\
& $\mathrm{IQ} \geq 70$ & $11(73.3)$ & $8(53.3)$ & $7(46.7)$ \\
\hline
\end{tabular}

Table 4. Statistical results of IQ score in each variables

\begin{tabular}{|c|c|c|c|c|c|}
\hline \multicolumn{2}{|c|}{ Variables } & \multirow{2}{*}{$\begin{array}{c}\mathrm{IQ}<70(\%) \\
5(12.5)\end{array}$} & \multirow{2}{*}{$\begin{array}{c}\mathrm{IQ} \geq 70(\%) \\
3(7.5)\end{array}$} & \multirow{3}{*}{$\begin{array}{c}\text { p-value } \\
0.290\end{array}$} & \multirow{3}{*}{$\begin{array}{c}\text { 95\% Confidence } \\
\text { Interval (CI) }\end{array}$} \\
\hline \multirow{2}{*}{ First-time Seizure Onset } & $<1$ year & & & & \\
\hline & $\geq 1$ year & $14(35)$ & $18(45)$ & & \\
\hline \multirow{2}{*}{ Etiology of Epilepsy } & Symptomatic & $9(22.5)$ & $8(20)$ & \multirow{2}{*}{0.393} & \multirow{2}{*}{$0.41-5.15$} \\
\hline & Idiopathic & $10(25)$ & $13(32.5)$ & & \\
\hline \multirow{2}{*}{ Type of Seizure } & Focal & $4(10)$ & $5(12.5)$ & \multirow{2}{*}{0.569} & \multirow{2}{*}{$0.19-3.79$} \\
\hline & General & $15(37.5)$ & $16(40)$ & & \\
\hline \multirow{2}{*}{ History of Family Seizure } & Presence & $2(5)$ & $2(5)$ & \multirow{2}{*}{0.658} & \multirow{2}{*}{$0.14-8.82$} \\
\hline & Absence & $17(42.5)$ & $19(47.5)$ & & \\
\hline \multirow{2}{*}{$\begin{array}{l}\text { History of Status } \\
\text { Epilepticus }\end{array}$} & Presence & $5(12.5)$ & $1(2.5)$ & \multirow{2}{*}{0.071} & \multirow{2}{*}{$0.75-67.98$} \\
\hline & Absence & $14(35)$ & $20(50)$ & & \\
\hline \multirow[t]{2}{*}{$\begin{array}{l}\text { Neuro-developmental } \\
\text { disorder comorbidity }\end{array}$} & Presence & $16(40)$ & $11(27.5)$ & \multirow[t]{2}{*}{$0.034^{*}$} & \multirow[t]{2}{*}{$1.08-21.76^{*}$} \\
\hline & Absence & $3(7.5)$ & $10(25)$ & & \\
\hline \multirow{4}{*}{$\begin{array}{c}\text { Type of Anticonvulsant } \\
\text { Usage }\end{array}$} & 1 type & $8(21.6)$ & $12(32.4)$ & \multirow{4}{*}{0.998} & \multirow{4}{*}{$0.23-6.71$} \\
\hline & 2 types & $6(16.2)$ & $6(16.2)$ & & \\
\hline & 3 types & $1(2.7)$ & $1(2.7)$ & & \\
\hline & $>3$ types & $2(5.4)$ & $1(2.7)$ & & \\
\hline \multirow{2}{*}{$\begin{array}{c}\text { Time of Anticonvulsant } \\
\text { Usage }\end{array}$} & 2 seizure episodes & $2(5.4)$ & $2(5.4)$ & \multirow{2}{*}{0.633} & \multirow{2}{*}{$0.15-9.57$} \\
\hline & $>2$ seizure episodes & $15(44.1)$ & $18(53)$ & & \\
\hline \multirow{2}{*}{ EEG Recording } & Normal & $1(2.7)$ & $1(2.7)$ & \multirow{2}{*}{0.729} & \multirow{2}{*}{$0.06-19.50$} \\
\hline & Abnormal & $16(44.4)$ & $18(50)$ & & \\
\hline \multirow{2}{*}{ CT Scan Imaging } & Normal & $3(21.4)$ & $1(7.1)$ & \multirow{2}{*}{0.179} & \multirow{2}{*}{$0.50-97.75$} \\
\hline & Abnormal & $3(21.4)$ & $7(50)$ & & \\
\hline
\end{tabular}

Legends: EEG: Electroencephalography, CT scan: Computer Topography scan; IQ: Intelligence Quotient

*Significant results

\section{Discussion}

It was found more children with epilepsy have IQ score $\geq 70$ (without $\mathrm{Cl}$ ) in our setting. This finding was similar with the study by Sherman et al., which reported more children with epilepsy with no $\mathrm{Cl}$ and the mean WISC IQ score was 78.62 points $^{9}$. Souza-Oliveira et al. also reported a higher mean IQ score, which was 89.58 points $^{10}$. Several studies reported contradictory results. El-Tallawy et al. reported 22 epileptic children (84.6\%) had Cl. Furthermore, Viscidi et al. also stated more epileptic children had $\mathrm{CI}$ with mean IQ score was 66.2 points $^{11}$. These different results are likely to be attributed to race or ethnic variety of the population. The ethnic differences could affect the cognitive measure in children with epilepsy, causing our results to be different from others.
In our study, neuro-developmental disorder comorbidity in children with epilepsy was significantly associated with lower cognitive function, such as cerebral palsy, ADHD, and mental retardation. Those disorders significantly caused lower IQ score, both with WISC and Stanford-Binet tests. In those conditions, the brain cortical regions' and other brain parts' damage will be increased so it can cause poor long-term seizure outcomes, and severe cognitive disability is one of them ${ }^{12,13,14}$. Qualman et al. reported neurological comorbidities significantly associated with epilepsy and also they negatively affected individual cognitive development of the child patients ${ }^{15}$.

Onset of first seizure was also reported to significantly relate to a child's impaired cognitive 
function. The younger the child had their first seizure, the more risk he/she would develop $\mathrm{Cl}^{7,9}$. This pattern of impairment caused by imbalance electrical damage from the seizure that strike immature brain, either generally or focally. It will delay maturation of the child's central nervous system, such as myelination process, mitotic cell activity, and development of brain neuron cells ${ }^{16}$

Idiopathic-generalized epilepsy (IGE) type was found higher in our population. This type has been reported to cause several cognitive deficits, such as attention, memory, verbal learning, and controlled sequential fine motor responses deficit, and also contributes to poor academic performance. Prassouli et al. described the poor academic performance of child IGE patients in a Greek schoolchildren population ${ }^{17}$. However, we found more patients with IQ score $\geq 70$ in the IGE type, and it was insignificantly correlated with $I Q$. This finding is in line with the study of Park et al. that reported normal intelligence function and insignificant correlations with cognition measurement in children with epilepsy ${ }^{18}$. Several factors such as good patient supervision with AED treatment control, late first-onset seizure in patient, and infrequent seizure episodes are confounding variables related to the IQ score of children with epilepsy.

Knowing the history of patients with epilepsy is essential to properly diagnose and predict future outcomes, including clinical and family history. Forty percent of patients with epilepsy are found to have a family history of epilepsy. Patients with a family history of seizures in their total relatives had higher rates of epileptic seizure episodes, but it was reported with lower rates of $\mathrm{Cl}$. One of the important clinical histories in epilepsy is the history of status epilepticus (SE). SE is a serious medical emergency condition that will cause poor impact in the cognition controller in specific brain regions such as neo cortex, amygdala, hippocampus, thalamus, and cerebellum because of the longer duration of electrical damage. Sheppard and Lippe illustrated some $\mathrm{Cl}$ in SE, such as lack of executive function, working memory, and motor ability ${ }^{19}$. Nevertheless, we found SE was insignificantly correlated with cognitive function in this study. It was likely because of AED use in children, so at the time of recording data we did not find any negative cognitive impact in children with epilepsy.

Type and number of AED dosage used can have the potential side effect of $\mathrm{Cl}$ in children with epilepsy, because it increases neuronal brain cells inhibition in cognitive regulator brain areas. If more drugs were given, the more severe the damage ${ }^{20,21}$. In our study, it is likely because of overlapping cognitive adverse effects of the drug with the seizure itself and/or neurological comorbidity, so the independent effect of drug is likely insignificant.

In children with epilepsy with $\mathrm{Cl}$, abnormal electroencephalography (EEG) and Computed Tomography (CT) scan result were likely to be found with one of the tests or both. Abnormal EEG results were found in $73 \%$ of focal seizure patients and in $76.9 \%$ of patients with general seizure, and respectively $50 \%$ and $34.6 \%$ for abnormal CT scan result 22 . Nevertheless, these findings were insignificantly correlated with cognitive impact in children with epilepsy. Since it was difficult to determine cognition effect with single imaging results, further study with continuous imaging is required to better determine the cognition impact on children with epilepsy.

We note several strengths in our study. We included data of all children with epilepsy available for analysis during a long-term period, with varying clinical history, onset, and usage of AED. This approach is expected to obtain a more complete picture of the child patients with epilepsy and its association with cognitive function in our setting. It is also describing how successful the management of epilepsy in order to prevent or control $\mathrm{Cl}$. However, there are limitations in our study, such as limited number of samples, use of observational design method, and omission of other possible comorbid factors including ethnic and social support, such as parental and classmate support. Further study is needed with larger samples and a prospective design, because in this study we do not evaluate what happens with the child's cognitive function in the future. A longitudinal approach will help a physician to better control and minimize the negative cognitive function effect in children with epilepsy.

\section{Conclusion}

Children epilepsy tended to have less effect on cognition function, which is marked by $I Q$ score with $\geq$ 70 points. Several factors contribute in this condition, but only neuro-developmental disorder comorbidity was found to significantly correlate with cognitive function in children with epilepsy. Further study with larger samples using a prospective design is needed to observe cognitive function change over time in children with epilepsy to determine suitable interventions for preventing further cognitive damage which will decrease their quality of life. 


\section{References}

1. Lilihata G, Handriastuti S. Epilepsi, In: Tanto C, Liwang F, Hanifati S, Pradipta EA, eds. Kapita Selekta Kedokteran edisi IV. Jakarta: Media Aesculapius. 2014:98-102

2. World Health Organization. Epilepsy: fact sheet [article]. WHO Media Centre [online]. 2017. Available at: http://www.who.int/mediacentre/factsheets/fs999/ en/. Accessed December 2, 2017

3. Raharjo TB. Faktor-Faktor Risiko Epilepsi pada Anak di bawah Usia 6 Tahun [Thesis]. Semarang: Universitas Diponegoro; 2007

4. Susilawati D. Subtes WISC Sebagai Pendukung Diagnosis Pada Anak ADHD [Thesis]. Yogyakarta: Universitas Gadjah Mada; 2013

5. Becker KA, History of the Stanford-Binet Intelligence Scales: Content and Psychometrics. Stanford-Binet Intelligence Scales, Fifth Edition Assessment Service Bulletin 2003;1:1-14

6. Karrasch M, Titta P, Hermann B, Joutsa J, Shinnar S, Rinnem J, et al. Cognitive outcome in childhood-onset epilepsy: a five-decade prospective cohort study. J Int Neuropsychol Soc 2017;22:1-9.

7. Rantanen K, Eriksson K, Nieminen P. Cognitive impairment in preschool children with epilepsy. Epilepsia 2011;52(8):1499-505. DOI: 10.1111/j.15281167.2011.03092.x.

8. Retnani HI. Korelasi Antara Konsentrasi Ferritin Serum dan Fungsi Kognitif pada Anak dengan Thalassemia Mayor [Thesis]. Yogyakarta: Universitas Gadjah Mada; 2013

9. Sherman EMS, Brooks BL, Fay-McClymont TB, MacAllister WS. Detecting epilepsy-related cognitive problems in clinically referred children with epilepsy: Is the WISC-IV a useful tool?. Epilepsia 2012;53(6):106066. DOI: 10.1111/j.1528-1167.2012.03493.x.

10. Souza-Oliveira C, Escosi-Rouset S, Funayama SS, Terra VC, Machado HR, Sakamoto AC. Intellectual functioning in pediatric patients with epilepsy: a comparison of medically controlled, medically uncontrolled, and surgically controlled children. J Pediatr (Rio J) 2010;86(5):377-83. DOI:10.2223/ JPED.2032.

11. Viscidi EW, Wyllie E, Sullivan S, Stanford L, Bulacio $\mathrm{J}$, Kotagal $\mathrm{P}$, et al. Mental retardation in pediatric candidates for epilepsy surgery: the role of early seizure onset. Epilepsia 2011;42(2):268-74.

12. Hrdlicka M, Komarek V, Propper L, Kulisek R, Zumrova A, Faladova, L, et al. Not EEG abnormalities but epilepsy is associated with autistic regression and mental functioning in childhood autism. Eur Child Adolresc Psychiatry 2004;13:209-13

13. El-Tallawy HN, Farghaly WMA, Shehata GA, Badry $\mathrm{R}$, Rageh TA, 2014. Epileptic and cognitive changes in children with cerebral palsy: an Egyptian study. Neuropsychiatric Dis Treat 2014;10:971-75. DOI: 10.2147/NDT.S59600.

14. Vasconcellos E, Wyllie E, Sullivan S, Stanford L, Bulacio J, Kotagal $P$, et al. Mental Retardation in pediatric candidates for epilepsy surgery: the role of early seizure onset. Epilepsia 2001;42(2):268-74.

15. Qualmann KJ, Spaeth CG, Myers MF, Horn PS, Holland K, Mangano FT, Greiner HM. Pediatric epilepsy surgery: the prognostic value of central nervous system comorbidities in patients and their families. J Child Neurol 2017;32(5):467-74. DOI: 10.1177/0883073816685653.

16. Aldenkamp AP. Effect of seizures and epileptiform discharge on cognitive function. Epilepsia 1997;38(1):852-55

17. Prassouli A, Katsarou E, Attilakos A, Antoniadou I. Learning difficulties in children with epilepsy with idiopathic generalized epilepsy and well-controlled seizures. Dev Med Child Neurol 2007;49:874-77. DOI: 10.1111/j.1469-8749.2007.00874.x

18. Park J, Yum MS, Choi H, Kim EH, Kim HW, Ko TS. Determine of intelligence in childhood-onset epilepsy: A single-center study. Epilepsy Behav 2013; 29: 16671. DOI: https://doi.org/10.1016/j.yebeh.2013.07.010

19. Sheppard E, Lippe S. Cognitive outcome of status epilepticus in children. Epilepsy Res Treat 2012;1-8. DOI: http://dx.doi.org/10.1155/2012/984124

20. Park SP, Kwon SH. Cognitive effects of antiepileptic drugs. J Clin Neurol 2008;4:99-106

21. Eddy CM, Rickards HE, Cavanna AE. The cognitive impact of antiepileptic drugs. Ther Adv Neurol Disord 2011;4(6):385-407. DOI: 10.1177/1756285611417920.

22. Baheti R, Gupta BD, Baheti R. A study of CT and EEG findings in patients with generalised or partial seizures in Western Rajasthan. J Indian Acad Clin Med 2003;4(1):25-29. 